\title{
Colonial-capitalism and the shrinking possibilities for achieving Aboriginal equality and agency in Australia: a critical study of 'economic' strategy for social and political advancement
}

\section{Lauren Fiedler}

University of Technology Sydney, Faculty of Arts and Social Sciences, PO Box 123, Ultimo NSW 2017, Australia. lauren.m.fiedler@student.uts.edu.au

DOI: https://doi.org/10.5130/nesais.v4i1.1525

\begin{abstract}
Subjectivity coded in Indigenous and non-Indigenous minds maintains a fictional spectre of Aboriginal deficiency and dependency. This essay argues that attempts to resist this narrative by economic means may serve in some ways to materially improve the lives of Indigenous peoples today, but are ultimately embedded in the western hegemony that continues to repress and inferiorise Aboriginal culture.
\end{abstract}

Keywords: settler colonialism; subjectification; self-determination; economism

First Nations peoples of Australia, whose traditional lands are incumbently covered by the Australian settler-state, were and continue to be subject to violent, state-mandated dispossession. Continued forms of domination exist as legacies of settler-colonialism and are marked by programmes of assimilation and coercive regulation of land claims and use. Currently, Indigenous peoples function within a schema of liberal democratic governmentality, in which social and economic policies are culturally pluralistic, but ultimately politically and economically hegemonic. The historic positioning of Indigenous peoples lingers on in a reiterated form of subjectification. 'Subjectification' will be used in this essay to refer to the Foucauldian notion which delineates the "modes by which human beings, in our culture, are made subjects" (Foucault 2000, p. 326). Subjectification is an inter-embedded process which can transgress and reconstitute Indigenous-settler social relations throughout its history.

Strategies to propel social and political change are born of and in response to settler-colonial attitudes, and therefore must be evaluated for the extent to which they wrest the individual and community from this enforced casting. Identifying, criticising and moving out of subjectivity is a deeply complex process, culminating in a variety of personal beliefs, community values and political strategy to transform the conditions of the present and direct towards the creation a peaceful and positive future. De-subjectification is ultimately a project of self-directed and innovated construction. Two vital heuristics have emerged from this process: self-determination and sovereignty. These methods are 
critical to rivaling the extremely destructive ensemble of social and political mechanisms leveraged by settler-colonists to domesticate, subordinate and eliminate Aboriginal people.

The process of moving away from introduced structures of domination is not by its own virtue necessarily anti-settler-colonial. Without the core elements of sovereignty and self-determination, hierarchical power dynamics relations operate 'underneath' and infiltrate Indigenous experiences. Elizabeth Povinelli uses the subterranean metaphor to illustrate how, upon invasion, westernised thought models and interpersonal and human-environmental relations were transmuted into neutral, natural, objective reality. The Indigenous project, then, ultimately strives to realise and re-assert legitimacy, facility and agency, using codes and values that predate, flow through and project beyond the actors and issues of today. Indigenous resistance demands that the authority and supremacy that the popular narrative has monopolised be challenged and eventually extinguished. Economic iterations of this project, I will argue, serve in some ways to materially improve the livelihoods of Indigenous peoples today, but are ultimately embedded in a destructive, divisive and unequal system. The social and political ends met by economic means are not transcendent and do not preserve or advance the Indigenous identity without subjectivity.

In Australia, racist theories motivated and characterised interactions between settlers and Indigenous actors in the early period of colonial contact and animated the material, structural dispossession of Aboriginal people. To systematically divide and conquer every element of life and supplant it with an ideology of supremacy and hegemony was to reap benefits for the invading powers, now and indefinitely into the future. Terra nullius was the fundamental legal and political instrument of this dispossession, and it was so successful in eliminating Indigenous agency via the tripartite inscription: people, land, and their linkage via the western model, property. Terra nullius produced an Indigenous subject with political demands centred on legal recognition of land rights and kinship structures: a relationship with the Australian settler-state in which Indigenous people are subjectified to reproduce "certain gestures, certain discourses, [and] certain desires" (Foucault 1982, p. 98). Australia's settlercolonial political and legal systems perpetuate a blind logic of linear hierarchy, political resistance to which is met with an unblinking refusal to acknowledge that present landownership is based on racial injustice (Keenan 2018).

Here we arrive at the crux of the economic problem: that land 'ownership' is the primary determinant of social and economic agency under the settler-colonial structure. This is compounded by an imagined supremacy inherited psycho-socially via a popular narrative that permeates governance, social relations and politics. This is the "skeleton of principle" that would be fractured (J. Brennan 1992; Cunliffe 2007) upon conceding to the logical conclusion that white ownership of "Australian" land is illegitimate. This facet was tellingly omitted from the 1992 Mabo decision to cancel the legal fiction of terra nullius.

It is my belief that granting Aboriginal people the North and Centre, as Cooper put it, would be providing concession to a level of social and economic mobility and agency for which there was no conceptual or pragmatic validity in 'white minds'. Even in a landmark case for Aboriginal social and political change, the potential for realising full sovereignty and self-determination was still statutorily limited. In her 1995 essay "Do Rocks Listen", Povinelli argued that Aboriginal traditions are legally productive because they are beliefs, not reality. The Mabo case demonstrates how the Australian nation can reconcile with multiculturalism, but this concession "ends where a conceptual 
accommodation to a multieconomism would begin." Cooper's query evidences the impermeable connection between settler-colonial cultural and economic domination. The question ignores the conditions of white positionality in manufacturing Indigenous inferiority. The thought "never having occurred" is clue itself to a world view engineered to eliminate the native (Wolfe 1999).

Prior to invasion, the sovereign Aboriginal human-environment nexus and emergent ways of knowing operated for approximately 80,000 years or more (The Guardian 2017). The system of relationships maintained by Aboriginal codes, morals, customs and pedagogies was evidently symbiotic and sustainable. Western, Judeo-Christian society is, in all aspects, diametrically the opposite of Aboriginal society (Foley 1988), the difference being, above all, compelled and characterised by capitalism. Marxist insights serve as useful analysis for linking the totalising power of capital and colonialism: the capitalist mode of production introduced to Australia and sustained through our political-legal system reproduces a violent, unjust and racist set of power relations that, in the neoliberal era, blend so seamlessly through society that to imagine the mutual exclusivity of capitalism and colonialism pertains to delusion. Similarly delusional is the fantasy of capitalist prosperity, 'participation' in which is akin to joining the crowd around the wellspring, waiting for the promised portion of wealth available to conscripts. The idyllic mirage of this system is a falsity: capitalism creates and sustains socio-economic inequality, relies on exploitation and destroys the environment. The dispossession visited on Aboriginal people at colonisation and to this day is a manifestation of the integrated socio-cultural and economic force of colonial-capitalism.

From the vantage point of this understanding, I argue that, in contrast to the liberal illusion separating the cultural and economic (that traditional Aboriginal "values and aspects of the old ways of life... are not inimical to economic progress"), that the pursuit of "private material wealth" by Aboriginal people (Langton 2012) is itself a cultural practice. It is the absorption into a system of life, or capitalist realism, that arrived and consumed the system of being that existed before it. This is the argument put forward by Mark Fisher's 2009 work wherein the phenomenon of global capitalist hegemony is evidenced in a crucial point: that it seems easier for most people to imagine the end of the world than the end of capitalism. It is important to highlight that under capitalism, a wage-worker has no choice but to sell their time and labour to private owners of land and resources within a nation-state. The illusion of choice is sustained by the 'freedoms' granted by personal wealth, consumerism, potential to grow one's own enterprise and the ability to leave the employment of one capitalist for another. Therefore, 'participants' in an economy don't belong to one owner as slaves would, instead they are owned collectively by a ruling capitalist class. Here is one way that sovereignty and self-determination is actually inimical to economism.

The project of self-determination and de-subjectification revolves around a belief in the sovereignty of pre-colonial Indigenous peoples and their power to choose their way of life. The economic strategy Langton advocates is deeply flawed, both in its reproduction of colonial-capitalist power relations and for its uneven service of the Aboriginal community. Improvements to the material conditions of Aboriginal lives afforded by the accumulation of material wealth is riveted to a particular milieu, predicated on capital, education afforded thusly and liberal-democratic social conditioning. The egalitarian, assimilationist presupposition of a universal liberalism motivates this advocacy. Langton's politics are symptomatic of a deeper neoliberal scourge emerging as a moralistic philosophy that conceptualises poverty as a product of the individual failings of the poor. This is doled out by the 
Daddy State of the neoliberal era that departs from the Nanny State of the late-liberal-stage Keynesian/Fordist political economics (Wacquant 2009). The Daddy state, Altman describes, accounts for a race-based shift in social policy. The problem of Indigenous poverty in the same areas Cooper wished to develop, previously explained in structural and historical terms, was redefined individualistically as a problem of Aboriginality. Such 'advocates' as Noel Pearson and Marcia Langton were the leaders of a blossoming educated, wealthy, Aboriginal middle class, and prescribed such conditions as those visible (or invisible) in the Northern Territory, to alcoholism and welfare dependence. An article in The Australian in 2008 attributed "the fresh portrait of the Aboriginal landscape sketched by Langton and Pearson" as having a "strong influence on public policy". Their controversial and 'brave' position was then directly linked to the instigation of the Northern Territory 'emergency response' or Intervention by the Howard government in 2007.

Purporting the 'failure' of the self-determination era, internalised racist rhetoric and individualising social program surfaces as 'behavioural neoliberalism' (Altman 2017). Andrew Hudson in 2015 summarised that "neoliberalism believes it is capitalism that should reform people, not the other way around." But participation in a pathogenic system that creates and perpetuates the very conditions of inequality the Aboriginal community is striving to undo is absolutely antithetical to the project of liberation of the colonial subject. Langton emerges in the 21 st century, as Cooper, Ferguson and Patten did in the early 20th century, as marshals of support, both ideological and financial, from wider society (Rowse 2010), but are ultimately ventriloquised by white opinion. This is where the branding by Aboriginal activists of Langton as a "renowned sellout" (Sovereign Union 2016) originates. Neither overdramatic nor needlessly crude, the title captures a grounded belief that reconciling Aboriginal culture with the imagined insularity of a capitalist economy is an underhanded way of labeling Indigenous people, as potential agents of a capitalist economy, available for purchase. What remains is an Aboriginal polity still struggling to mitigate the effects of their subjective governmentality, let alone win self-governance. With vast numbers in juvenile justice and incarceration (Aboriginal people in Australia are the most incarcerated people in the world) and subject to systematic surveillance, behavioural modification and abuse by the state and, by extension, corporations. Therefore, self-determination and sovereignty cannot be cast aside as fruitless projects when they have never, ever been fully or uniformly realised.

Granted, engaging economic facility today can look very successful; Wiradjuri woman Laura Berry, CEO of Supply Nation said in 2018 that Indigenous businesses can foster momentous change within a whole community, and her research shows that for every dollar of revenue, Indigenous businesses produce on average $\$ 4.41$ of social return (Indigenous X 2018). Some other Aboriginal businesses include Blacka Wear, Bracks Design and AllGrid, enterprises that combine Aboriginal values with business practice, delivering positive and sustainable outcomes to suppliers and customers. The Darkinjung Land Council is the biggest private property owner in the Gosford region of New South Wales, and estimates its current projects are worth more than $\$ 900$ million to the local economy over the next two decades (ABC News 2016). Admonishment of these demonstrations of economic strategy would be to undermine the intelligibility of Aboriginal people as agents, exercising selfdetermination, albeit in this insulated capitalistic capacity.

Beyond the colonial-capitalist realm, however, Aboriginal communities around Australia have begun to successfully declare independence, in a fulfillment of the demands that defined the land-rights era 
of Aboriginal political history. In the 1978 Inquiry, South Coast elders, prominent among them Gaboo Thomas, Percy Mumbulla and Jack Campbell demanded "...to be given back enough of our land with the guarantee that white people can never again take it from us...so that we can live independent of government." Now, such nations as the Murrawarri, Waradjuri, Yidinji, Eualayi and PitjantjatjaraYankunytjatjara have achieved sovereignty and self-determined governmentality so as to now "take care of their own affairs" (Foley 1988). Is this what progress looks like to Langton?

Ultimately, Aboriginal people have the right to configure their own lives and destinies, and all psychosocial and systemic barriers to this should be identified and removed. Progress to social and political change for First Nations peoples may take many forms, but an economic strategy conceived of a misjudgment of the nature of capital is no guarantee for advancement or liberation from subjectification. The neoliberal argument in this context implies that family background and social structure should and do matter less for social mobility and economic gains, and effort and ability will matter more. Time and comparative evidence demonstrates, however, that absorption in capitalism might actually restrict, rather than promote, equality (M. Western, J. Baxter, J. Pakulski et al. 2007).

Subjectivity coded in Indigenous and non-Indigenous minds maintains a fictional spectre of Aboriginal deficiency and dependency. So, self-determination and sovereignty, undergoing periods of adjustment in modality, work in diverse and surprising ways to revive the truth of Aboriginal facility that was diminished by the invading structure dictating political strategy today. Ultimately, what is garnered from an examination of economisation in Indigenous politics goes beyond the tired, negative narrative of Indigenous struggle 'falling short'. Instead, we may gain a more complete picture of the insidious, divisive ways colonial-capitalism, through economisation, forecloses the avenues of departure from hegemonic power, and thus reiterates settler sovereignty (Tuck \& Yang 2012).

\section{References}

Altman, J. 2017, 'Behavioural neoliberalism in the Australian outback: The quest to alter Indigenous subjectivity', Australian National University, School of Regulation and Global Governance, accessed June 2018, <http://regnet.anu.edu.au/news-events/news/7025/behavioural-neoliberalism-australianoutback-quest-alter-indigenous $>$

The Australian, 2008, 'Indigenous insiders chart an end to victimhood', accessed June 2018, $<$ https://www.theaustralian.com.au/arts/indigenous-insiders-chart-an-end-to-victimhood/newsstory/f61efd2dbcef50c3518e1c5bfe8364d2?sv=368d724afd33ac2b56c5f934b16ef082>

Cunliffe, E. Ph.D, 2007, 'Anywhere But Here: Race and Empire in the Mabo Decision', Social Identities, vol. 13, no. 6, 751-768. https://doi.org/10.1080/13504630701696435

Davidson, H. \& Wahlquist, C. 2017, 'Australian dig finds evidence of Aboriginal habitation up to 80,000 years ago', The Guardian, accessed June 2018, < https://www.theguardian.com/australianews/2017/jul/19/dig-finds-evidence-of-aboriginal-habitation-up-to-80000-years-ago $>$ 
E. Tuck \& K.W. Yang, 2012, 'Decolonization is not a metaphor', Decolonization: Indigeneity, Education \& Society, Vol. 1, No. 1, 2012, pp. 1-40 2012

Fisher, M. 2009, Capitalist Realism: is there no alternative? Chapter 1, Zero Books.

Foley, G. 1988, Speech to the Rainbow Alliance conference, 'For Aboriginal Sovereignty', Arena, Issue 83.

Foucault, M. 1980, 'Power/Knowledge: Selected Interviews and Other Writings' in C. Gordon (Ed. \& Trans.), Two Lectures, Pantheon Books, New York, NY, pp. 78-108.

Foucault, M. 2000, 'Power: Volume 3: Essential Works of Foucault' in The Subject and Power, J.D. Faubion (Ed.). R. Hurley (Trans.), Penguin Books, pp. 326-348.

Keenan, S. 2018, 'Australia's White Fragility', Verso Blog, accessed May 2018, $<$ https://www.versobooks.com/blogs/3702-australia-s-white-fragility-sarah-keenan>

Langton, M. 2012, 'Lecture 5 - Counting Our Victories: the end of Garvey-ism and the soft bigotry of low expectation' in The Quiet Revolution: Indigenous People and the Resources Boom, ABC Boyer Lectures, accessed May 2018, <http://www.abc.net.au/radionational/programs/boyerlectures/2012boyer-lectures-245/4427682\#transcript $>$

Povinelli, E.A. 1995, 'Do Rocks Listen? The Cultural Politics of Apprehending Australian Aboriginal Labour', American Anthropologist, vol. 97, no. 3. https://doi.org/10.1525/aa.1995.97.3.02a00090

Vince, M. 2016, 'Darkinjung Land Council says racism is hampering Indigenous development on NSW Central Coast', ABC News Central Coast, accessed June 2018, $<\underline{\text { http://www.abc.net.au/news/2016-03-03/darkinjung-land-council-racism-hamper- }}$ development/7214836>

Western, M., Baxter, J., Pakulski, J., Tranter, B., Western, J. et al., Spring 2007, 'Neoliberalism, Inequality and Politics: The Changing Face of Australia', Australian Journal of Social Issues, Sydney, vol. 42, no. 3, pp 401-418, 286-287.

Wolfe, P. 2006, 'Settler colonialism and the elimination of the native', Journal of Genocide Research, December, pp. 387-409. https://doi.org/10.1080/14623520601056240 